\title{
SOME PHYSIOLOGICAL AND HISTOLIGICAL MEASUREMENTS IN THE REPRODUCTIVE SYSTEM OF MUSCOVY, PEKIN DUCKS AND THEIR CROSS 2- FEMALE REPRODUCTIVE SYSTEM
}

\author{
BAKIR, A. A. ${ }^{1}$, A. A. AMER ${ }^{2}$, K. A. KHIMSAWY ${ }^{2}$ AND A. M. H. EL-SHEIKH ${ }^{1}$ \\ 1. Animal Prod. Research Institute, ARC, Dokki, Giza \\ 2. Faculty Of Agriculture, Al-Azhar University
}

(Manuscript received 13 December, 2010)

\begin{abstract}
This study was carried out to detect the differences in some physiological aspects of female reproductive system of Muscovy, Pekin ducks and their intergeneric Hybrid cross. Fifty days old female ducklings from each breed and cross were raised until 25 weeks of age. Ovary, oviduct weights and oviduct length, histological measurements of the ovary and serum progesterone and estradiol concentrations were measured at 4, 8, 12, 16 and 22 weeks of age. The results indicated that there were significant differences between breeds in the studied physiological aspects of the female reproductive system. Crossing between Muscovy males and Pekin females produced intergeneric sterile birds which are known as mule ducks. All characteristic studies of the female reproductive system of these Hybrid ducks were physiologically and histologically abnormal as compared to Muscovy or Pekin ducks.
\end{abstract}

\section{INTRODUCTION}

Ducks are considered as one of the most useful species of lame birds; they require relatively cheep feed and simple houses and suffer less from disease problems. Genetic selection programs carried out over the past three decades have led to the development of number of significantly improved lines of ducks. Such programs have been applied to Muscovies, as well as Pekin- type ducks with good success. Mating between Muscovies and common ducks produces intergeneric sterile hybrids characterized by unique growth and excellent cross characteristics. Studies on reproductive characteristics of such breeds are of particular importance in order to quality of their reproductive efficiency. Vernerova and Burda (1984) identified 4 growth phases of the ovarias in Pekin ducks : fast (1-30 days of age), moderate (30130 days of age), intensive (130-160 days of age) and regression at the end of egg production period. Rojanastid et al. (1990) indicated that progesterone concentration increased the granules in layers of some ovarian follicles of Muscovy ducks, whereas estradiol in the surrounding theca layers is decreased. The aim of the present study is to detect the differences in some physiological and histological aspects in the female reproductive system of Muscovy, Pekin ducks and their cross (Muscovy $\times$ Pekin). 


\section{MATERIALS AND METHODS}

The present work was carried out at the Poultry Research Station, Animal production Department, Faculty of Agriculture, Al-Azhar University. Fifty females one day old duckling from each of Muscovy, Pekin and Hybrid ducks (Muscovy $\times$ Pekin) were used to compare some physiological and histological traits of their reproductive systems. After hatching all ducklings were wing-banded and brooded in battery cages till the end of the 4 weeks of age, then transported to open system floor pens. They received continuous light for the first three weeks and then $14 \mathrm{hr} /$ day till 25 weeks of age. Birds were fed ad libitum rations according to NRC (1994) during different stages (starter 0-2 wks, grower 3-7 wks and breeder from 8 to the end of experiment) 22, 16 and $15 \%$ crude protein, 2900, 3000 and $2900 \mathrm{Kcal} \mathrm{ME} / \mathrm{kg}$ diet, 0.65, 0.60 and 2.75 $\%$ calcium and available phosphorous $0.40,0.30$ and $0.35 \%$, respectively, and water was available continuously. At 4, 8, 12, 16 and 22 weeks of age, three females from each breed were randomly chosen for some ovary and oviduct measurements and serum progesterone and estradiol estimation. However, histological study on the ovaries was performed only at 22 weeks of age.

\section{Ovary and oviduct measurements}

Birds were weighed to the nearest gram, and the ovary and oviduct were dissected and weighed to the nearest milligram, and their percentages to live body weight were calculated. Length of the oviduct was measured to the nearest $\mathrm{cm}$.

\section{Blood sampling and hormonal assay}

Blood samples were withdrawn from the brachial vein and centrifuged to obtain serum which was stored at $-20{ }^{\circ} \mathrm{C}$. Serum progesterone and estradiol were estimated by using radioimmunoassay procedure using commercial Kits according to Miller (1988) and Sizonenko (1987).

\section{Histological preparation and examination}

A part of the mid portion of each dissected ovary was immediately fixed in formalin solution, and histological sections were prepared. Histological examination and measurements in micron $(\mu)$ were performed using a carlizis microscope and the eye piece micrometer scale. The following histological parameters were calculated according to Amin (1966):

1 - Volume of the follicle external.

2- Volume of the follicle internal.

3- Volume of lumen of the follicle.

4- Volume of cell.

5- Volume of nucleus. 
The volume of these structures was collected using the following formula:

$P=4 / 3 \sqcap a(b)^{2}$

Where $P=$ volume, $4 / 3=$ constant, $n=22 / 7, a=1 / 2$ the largest diameter and $b=$ $1 / 2$ the smallest diameter.

The average of each parameter was obtained by measuring 10 random follicles.

\section{Statistical Analysis}

All data were subjected to analysis of variance and Duncan's multiple range test (Duncan, 1955) procedures within the statistical analysis system of SAS software (SAS, 1985).

\section{RESULTS AND DISCUSSION}

\section{Ovary and oviduct measurements}

Results of ovary and oviduct weights (absolute and relative), and oviduct length in different breeds of ducks at various ages are presented in Table 1.

\section{1- Ovary weight}

Significant differences between breeds in absolute and relative ovary weight were observed at all studied ages except at 12 weeks of age. On the other hand, the ovary in Hybrid ducks was not observed at 4 weeks of age. It is clear that Pekin ducks were significantly superior to the other two breeds in each of absolute and relative ovary weight at 4, 8 and 16 weeks of age. At 22 weeks of age, Hybrid ducks were observed to have significantly the lowest absolute and relative ovary weight. Developmental changes in the female reproductive organs were more marked prior to sexual maturity than after its attainment. Therefore, the relative weight of the reproductive organs showed irregular increase before six months of age till sexual maturity (Kamar and Yamani, 1980).

\section{2- oviduct weight and length}

Significant differences between breeds in absolute and relative oviduct weight were observed at all studied ages except relative weight at 16 weeks of age. It is clear that Pekin ducks were significantly superior to the other two breeds in each of absolute and relative oviduct weight at 4, 8, 12 and 22 weeks of age. At 16 weeks of age, the significant highest absolute oviduct weight was recorded for Hybrid ducks. On the other hand, significant differences between breeds in oviduct length were observed at all studied ages except at 8 and 12 weeks of age (Table 1). Pekin ducks were observed to have significantly the highest length than Muscovy ducks at 4 and 22 weeks of age, while, at 16 weeks of age the 
significantly lowest oviduct length was recorded for Pekin ducks. Hybrid ducks

were observed to have significantly the lowest oviduct length at 22 weeks of age.

\section{Serum progesterone and estradiol}

Progesterone and estradiol concentrations in serum of different breeds of ducks are presented in Table 2. Gradual increase in serum progesterone concentration was observed by advancing age until it reached $0.71,0.47$ and $0.78 \mathrm{ng} / \mathrm{ml}$ and estradiol reached $310.0,286.7$ and $52.7 \mathrm{pg} / \mathrm{ml}$ at sexual maturity stage (22 weeks of age) in Pekin, Muscovy and Hybrid ducks, respectively. From 4 to 22 weeks of age the significantly highest serum progesterone concentration was recorded for Hybrid ducks, while, significantly lower serum progesterone concentration was noticed in Muscovy ducks. On the other hand, no significant differences in serum progesterone concentration were observed between Pekin and Hybrid ducks through the period from 4 to 22 weeks of age. Also, it is clear that Hybrid ducks were significantly lower to the other two breeds in serum estradiol concentration. This result is excepted because there were no ovarian follicles in Hybrid ovary which produces estradiol. Significant higher serum estradiol concentration was noticed in Pekin ducks through the period from 4 to 22 weeks of age. Results obtained in the present study in Muscovy ducks are in agreement with those reported by Rojanastid et al., (1990) who found that the concentration of progesterone increased the granules of layers of same follicles whereas estradiol in the surrounding theca layers decreased in Muscovy ducks. On the other hand, the increase in the $\mathrm{P}_{4}$ receptor binding before oviposition is assumed to be caused by the ovarian steroid hormones, estradiol- $17 \beta\left(E_{2}\right)$, or testosterone $(T)$ or both, because the secretion of these hormones increased several hours before oviposition $E_{2}$ ( Lague et al., 1975 and T : Johnson and Tienhoven, 1980). Also, in laying hens, $E_{2}$ and $T$ may contribute indirectly to oviposition by increasing the $\mathrm{P}_{4}$ receptor binding relating to the arginine vasotocin action for oviposition as postulated previously (Takahashi et al., 1994). On the other hand, Johnson (1984) suggested that the rise in plasma $\mathrm{P}_{4}$ precedes and stimulates the rise of Leutinizing hormone (LH) and a positive feedback between $\mathrm{P}_{4}$ and $\mathrm{LH}$ results in the hormone peaks that induced ovulation.

\section{Histological examination of the ovary}

Histological measurements of the ovary of different duck breeds at 22 weeks of age are presented in Table 3. Volume of follicles (external and internal) in Muscovy duck were larger than in Pekin duck (more than double). On the contrary, Pekin duck showed larger volume of lumen, cell and volume of nucleus than Muscovy duck. Histological sections in the ovary of Pekin, Muscovy and Hybrid ducks at 22 weeks of age are illustrated in Figs. 1, 2 and 3 respectively. Microscopic examination showed 
that no Graffian or any follicle in ovary of Hybrid duck (Fig. 3) and clusters of epithelial dells formed no distinct ovarian structure. However, some areas were noticed with no scallerd cells indicating degenerated follicles.

Table 1. Ovary and oviduct measurements in different breeds of ducks at different ages (Means \pm S.E).

\begin{tabular}{|c|c|c|c|c|}
\hline $\begin{array}{c}\text { Age } \\
\text { (weeks) }\end{array}$ & $\begin{array}{c}\text { Ovary and oviduct } \\
\text { measurements }\end{array}$ & Pekin & Muscovy & Hybrid \\
\hline 4 & $\begin{array}{l}\text { Ovary weight (g) } \\
\text { Relative ovary weight (\%) } \\
\text { Oviduct weight (g) } \\
\text { Relative oviduct weight (\%) } \\
\text { Oviduct length (cm) }\end{array}$ & $\begin{array}{l}0.95 \pm 0.003^{\mathrm{a}} \\
0.014 \pm 0.001^{\mathrm{a}} \\
0.12 \pm 0.0006^{\mathrm{a}} \\
0.017 \pm 0.0009^{\mathrm{a}} \\
9.53 \pm 0.57^{\mathrm{a}}\end{array}$ & $\begin{array}{l}0.027 \pm 0.003^{b} \\
0.004 \pm 0.004^{b} \\
0.05 \pm 0.003^{c} \\
0.008 \pm 0.0002^{b} \\
7.93 \pm 0.15^{b}\end{array}$ & $\begin{array}{l}* * \\
* * \\
0.09 \pm 0.006^{b} \\
0.015 \pm 0.0013^{a} \\
9.57 \pm 0.09^{a}\end{array}$ \\
\hline 8 & $\begin{array}{l}\text { Ovary weight (g) } \\
\text { Relative ovary weight (\%) } \\
\text { Oviduct weight }(\mathrm{g}) \\
\text { Relative oviduct weight (\%) } \\
\text { Oviduct length (cm) }\end{array}$ & $\begin{array}{l}0.25 \pm 0.027^{a} \\
0.015 \pm 0.001^{a} \\
0.39 \pm 0012^{a} \\
0.024 \pm 0.003^{a} \\
14.07 \pm 0.5\end{array}$ & $\begin{array}{l}0.12 \pm 0.003^{b} \\
0.005 \pm 0.005^{b} \\
0.24 \pm 0.02^{b} \\
0.011 \pm 0.004^{b} \\
12.43 \pm 0.43\end{array}$ & $\begin{array}{l}0.02 \pm 0.003^{c} \\
0.007 \pm 0.003^{b} \\
0.12 \pm 0.012^{c} \\
0.006 \pm 0.0007^{c} \\
13.47 \pm 0.54\end{array}$ \\
\hline 12 & $\begin{array}{l}\text { Ovary weight (g) } \\
\text { Relative ovary weight (\%) } \\
\text { Oviduct weight (g) } \\
\text { Relative oviduct weight (\%) } \\
\text { Oviduct length (cm) }\end{array}$ & $\begin{array}{l}0.45 \pm 0.015 \\
0.018 \pm 0.0009 \\
0.66 \pm 0.021^{a} \\
0.027 \pm 0.003^{a} \\
15.37 \pm 0.35\end{array}$ & $\begin{array}{l}0.30 \pm 0.012 \\
0.011 \pm 0.0003 \\
0.28 \pm 0.009^{c} \\
0.01 \pm 0.002^{b} \\
15.20 \pm 0.32\end{array}$ & $\begin{array}{l}0.36 \pm 0.036 \\
0.037 \pm 0.025 \\
0.47 \pm 0.05^{b} \\
0.01 \pm 0.0003^{b} \\
14.73 \pm 0.73\end{array}$ \\
\hline 16 & $\begin{array}{l}\text { Ovary weight (g) } \\
\text { Relative ovary weight (\%) } \\
\text { Oviduct weight (g) } \\
\text { Relative oviduct weight (\%) } \\
\text { Oviduct length (cm) }\end{array}$ & $\begin{array}{l}0.61 \pm 0.009^{a} \\
0.024 \pm 0.0003^{a} \\
0.76 \pm 0.023^{b} \\
0.029 \pm 0.001 \\
14.87 \pm 0.26^{b}\end{array}$ & $\begin{array}{l}0.49 \pm 0.023^{b} \\
0.017 \pm 0.0006^{b} \\
0.71 \pm 0.577^{b} \\
0.025 \pm 0.009 \\
15.97 \pm 0.18^{a}\end{array}$ & $\begin{array}{l}0.48 \pm 0.026^{b} \\
0.014 \pm 0.0019^{b} \\
0.97 \pm 0.046^{a} \\
0.028 \pm 0.0026 \\
15.43 \pm 0.27^{a}\end{array}$ \\
\hline 22 & $\begin{array}{l}\text { Ovary weight }(\mathrm{g}) \\
\text { Relative ovary weight (\%) } \\
\text { Oviduct weight }(\mathrm{g}) \\
\text { Relative oviduct weight (\%) } \\
\text { Oviduct length (cm) }\end{array}$ & $\begin{array}{l}* 87.9 \pm 2.88^{a} \\
* 3.36 \pm 0.03^{a} \\
72.1 \pm 0.79^{a} \\
2.76 \pm 0.05^{a} \\
60.23 \pm 0.79^{a}\end{array}$ & $\begin{array}{l}* 86.93 \pm 1.89^{a} \\
* 2.77 \pm 0.03^{b} \\
68.33 \pm 0.86^{b} \\
2.19 \pm 0.01^{b} \\
51.93 \pm 1.13^{b}\end{array}$ & $\begin{array}{l}0.68 \pm 0.07^{b} \\
0.02 \pm 0.002^{c} \\
2.17 \pm 0.24^{c} \\
0.06 \pm 0.01^{c} \\
16.3 \pm 0.52^{c}\end{array}$ \\
\hline
\end{tabular}

** Ovary is not visually observed.

* Ovary weight with follicles in Pekin and Muscovy ducks at 22 weeks of age.

$a, b, c=$ Means within each row with the same letter are not significantly different $(P \leq 0.05)$. 
Table 2. Serum steroid hormones concentration in different breeds of ducks at different ages (Means \pm S.E).

\begin{tabular}{|c|c|c|c|c|}
\hline $\begin{array}{c}\text { Age } \\
\text { (weeks) }\end{array}$ & Hormones & Pekin & Muscovy & Hybrid \\
\hline 4 & $\begin{array}{l}\text { Progesterone }(\mathrm{ng} / \mathrm{ml}) \\
\text { Estradiol }(\mathrm{pg} / \mathrm{ml})\end{array}$ & $\begin{array}{l}0.15 \pm 0.03^{\mathrm{ab}} \\
29.7 \pm 4.26^{\mathrm{a}}\end{array}$ & $\begin{array}{l}0.05 \pm 0.05^{\mathrm{b}} \\
19.0 \pm 0.58^{\mathrm{b}}\end{array}$ & $\begin{array}{r}0.24 \pm 0.02^{\mathrm{a}} \\
0^{\mathrm{c}}\end{array}$ \\
\hline 8 & $\begin{array}{l}\text { Progesterone }(\mathrm{ng} / \mathrm{ml}) \\
\text { Estradiol }(\mathrm{pg} / \mathrm{ml})\end{array}$ & $\begin{array}{l}0.20 \pm 0.04^{\mathrm{ab}} \\
73.3 \pm 8.82^{\mathrm{a}}\end{array}$ & $\begin{array}{l}0.08 \pm 0.04^{b} \\
22.0 \pm 2.52^{b}\end{array}$ & $\begin{array}{l}0.40 \pm 0.12^{\mathrm{a}} \\
27.7 \pm 4.33^{\mathrm{b}}\end{array}$ \\
\hline 12 & $\begin{array}{l}\text { Progesterone }(\mathrm{ng} / \mathrm{ml}) \\
\text { Estradiol }(\mathrm{pg} / \mathrm{ml})\end{array}$ & $\begin{array}{l}0.27 \pm 0.03^{\mathrm{ab}} \\
85.0 \pm 7.63^{\mathrm{a}}\end{array}$ & $\begin{array}{l}0.20 \pm 0.04^{b} \\
40.7 \pm 4.37^{b}\end{array}$ & $\begin{array}{l}0.44 \pm 0.11^{\mathrm{a}} \\
30.0 \pm 6.0^{\mathrm{c}}\end{array}$ \\
\hline 16 & $\begin{array}{l}\text { Progesterone }(\mathrm{ng} / \mathrm{ml}) \\
\text { Estradiol }(\mathrm{pg} / \mathrm{ml})\end{array}$ & $\begin{array}{l}0.50 \pm 0.07^{\mathrm{a}} \\
276.7 \pm 64.38^{\mathrm{a}}\end{array}$ & $\begin{array}{l}0.22 \pm 0.01^{\mathrm{b}} \\
136.7 \pm 1.73^{\mathrm{b}}\end{array}$ & $\begin{array}{l}0.55 \pm 0.13^{\mathrm{a}} \\
36.3 \pm 7.42^{\mathrm{c}}\end{array}$ \\
\hline 22 & $\begin{array}{l}\text { Progesterone }(\mathrm{ng} / \mathrm{ml}) \\
\text { Estradiol }(\mathrm{pg} / \mathrm{ml})\end{array}$ & $\begin{array}{l}0.71 \pm 0.05^{\mathrm{ab}} \\
310.0 \pm 40.41^{\mathrm{a}}\end{array}$ & $\begin{array}{l}0.47 \pm 0.04^{\mathrm{b}} \\
286.7 \pm 48.42^{\mathrm{a}}\end{array}$ & $\begin{array}{l}0.78 \pm 0.03^{\mathrm{a}} \\
52.7 \pm 8.51^{\mathrm{b}}\end{array}$ \\
\hline
\end{tabular}

$a, b=$ Means within each row with the same letter are not significantly different $(P \leq 0.05)$.

Table 3. Histological measurements $(\mu)$ in the ovary of different breeds of ducks at 22 weeks of ages (Means \pm S.E).

\begin{tabular}{|l|c|c|c|}
\hline \multicolumn{1}{|c|}{ Measurements } & Pekin & Muscovy & Hybrid \\
\hline Volume of follicle : & & & $0 *$ \\
External & 141.60 & 317.83 & 0 \\
Internal & 121.77 & 295.85 & 0 \\
\hline Volume of lumen & 28.83 & 22.0 & 0 \\
\hline Volume of cell & 1.36 & 0.63 & 0 \\
\hline Volume of nucleus & 0.15 & 0.07 & 0 \\
\hline
\end{tabular}

* There are no ovarian follicles detected in the ovarian histological structure of Hybrid duck. 


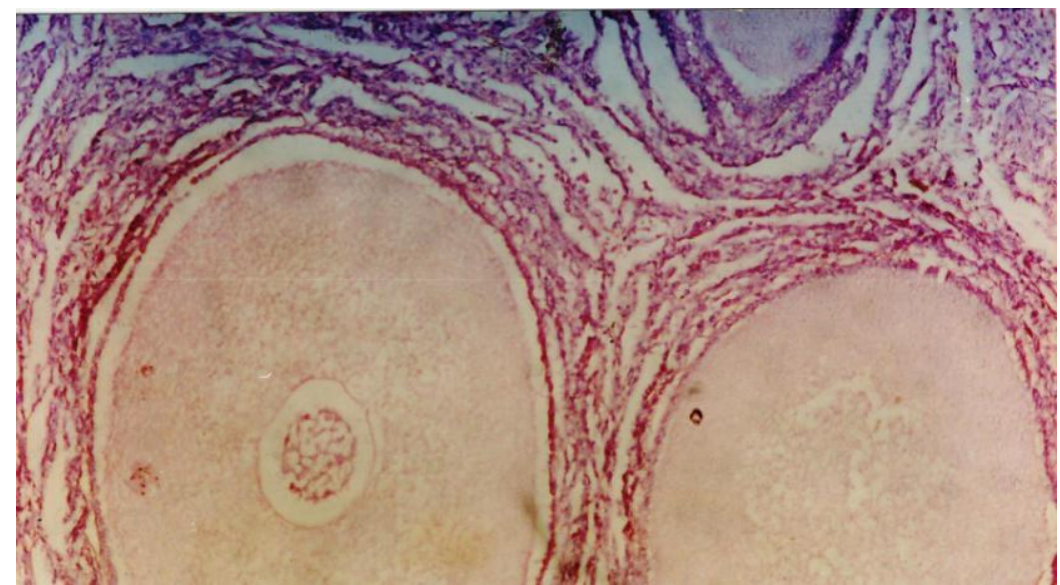

Fig. 1. Section in Pekin ducks ovary at 22 wks of age (X129).

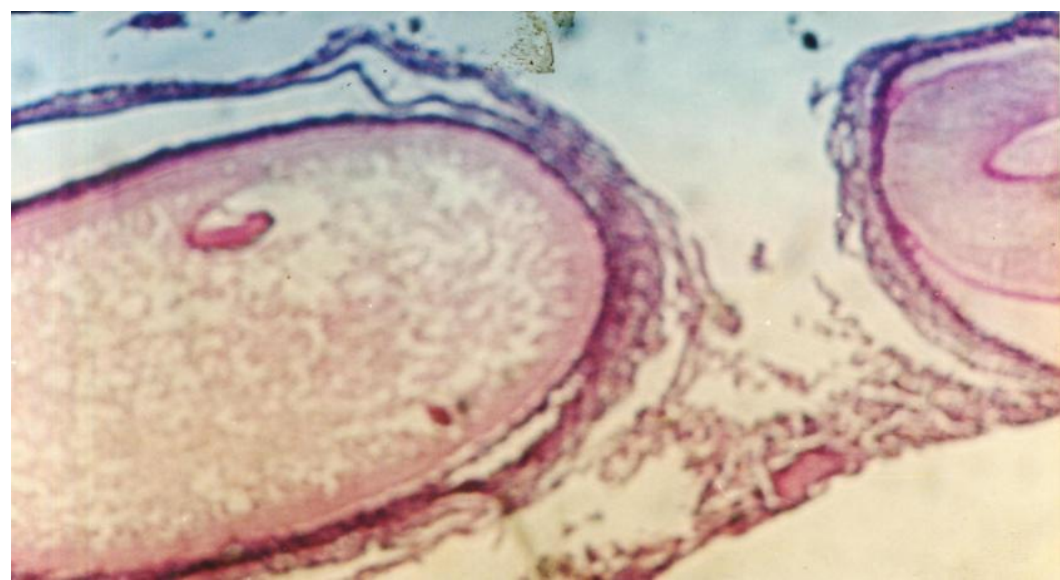

Fig. 2. Section in Muscovy ducks ovary at 22 wks of age (X129).

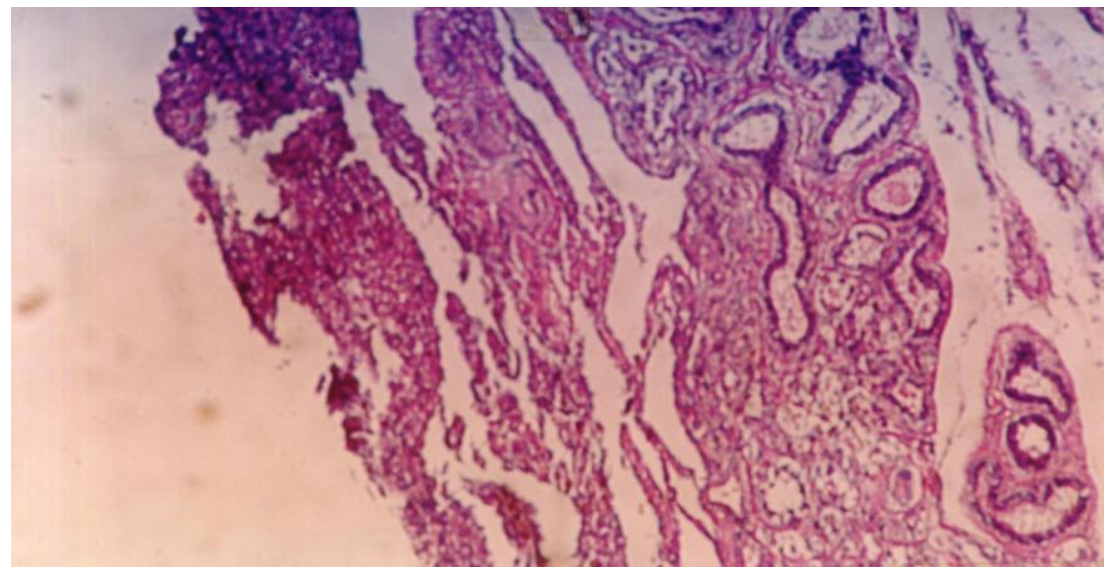

Fig. 3. Section in Hybrid ducks ovary at 22 wks of age (X129) 


\section{REFERENCES}

1. Amin, S. O. 1966. Change in histology of Egyption buffaloes carpus luteum in its function and activity. Thesis, Ph.D. Ain Shams University, Egypt.

2. Duncan, D. B. 1955. Multiple range and multiple F- test, Biometrics 11:1-42.

3. Johnson, A. L. and A. Van Tienhoven. 1980. Plasma concentrations of sex steroids and LH during the ovulatory cycle of the hen, Gallus domesticus. Biol. Reprod. 23: 386-393.

4. Johnson, A. L. 1984. Interactions of progesterone and Luteinising hormone leading to ovulation in the domestic hen. Pages 133-143 in : reproductive Biology of Poultry. F. J. Cunninghan, P. E. Lake and D. Hewitt, ed. British Poultry science Ltd., Edinbourgh, UK.

5. Kamar, G. A. R, and K. A. Yamani. 1980. Differential growth in the different organ of ducks. Egypt j. Ainim. Prod. 20: 44-53.

6. Lague, C., Tienhoven, A.Van. and F. J. Cunningham. 1975. Concentrations of estrogen, progesterone and LH during the ovulatory cycle of the laying chicken (Gallus domesticus). Biol. Reprod. 12:590-598.

7. Miller, W. L. 1988. Molecular Biology of Steroid Hormone Synthesis. Endocrine Reviews 9 (3): 295-318.

8. N. R. C. National Research Council. 1994. Nutrient Requirements of Poultry. 9th rev. ed. National Academy Press, Washington, D.C.

9. Rojanastid, S., N. Chaiyanukulkitti and A. Pusittigul. 1990. Use of sago palm meal, palm kernel cake and rubber seed meal as basal feed for Muscovy. Thurakit Ahan Sat. 7(25) : 28-39

10. SAS Institute. 1985. SAS/ STAT User's Guide. Release 6-03 Edition: SAS institute In., Cary NC U. S. A.

11. Sizonenko, P. C. 1987. Normal sexual maturation. Pediatrician, 14:191-201.

12. Takahashi, T., M. Kawashima, M. Kamiyoshi and K. Tanaka. 1994. Arginine vasotocin receptor binding in the hen uterus (shell gland) before and after oviposition. Eur. J. Endocrinol. 130:366-372.

13. Vernerova, E. and Z. Burda. 1984. Development of female sexual organs in ducks.: Sbornik Zivocisna vyroba 41: 175-189. 


\section{بعض المقاييس الفسيولوجية و الهستولوجية فى الجهاز التناسلى}

\section{للبط المسكوفى والبكينى وخليطهما}

$$
\text { - - - الجهاز التناسلى الأثثوى }
$$

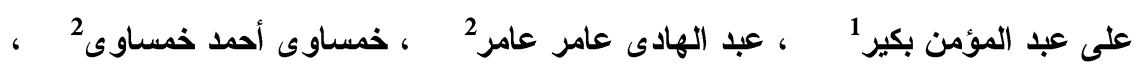

على محمد حسن الثيخ عامر عامر 1

$$
\begin{aligned}
& \text { (I) معر بحوث الإنتاج الحيو/نى - وزارة الزراعة - الدقى - الجبزة } \\
& \text { (r) كلبة الزراعة - جامعة الأزهر - مدينة نصر - القاهرة }
\end{aligned}
$$

أجريت هذه الدر اسة لتوضيح الاختلافات فى بعض الصور الفسيولوجية و الهستولوجية فى

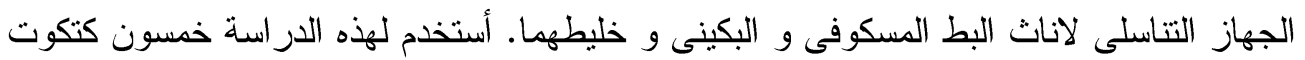

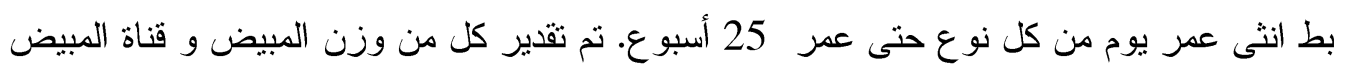

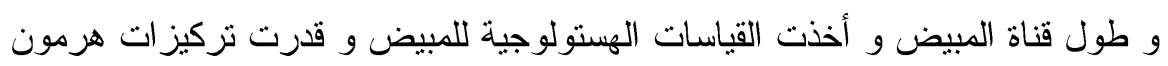

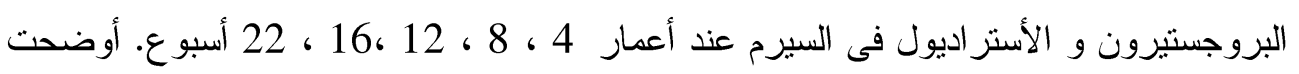

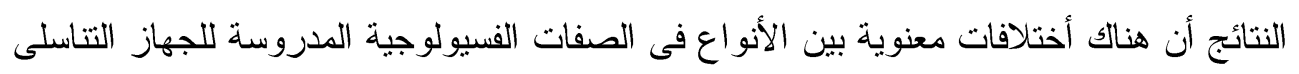

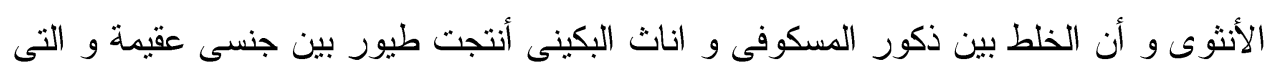

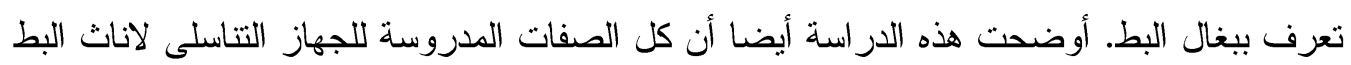

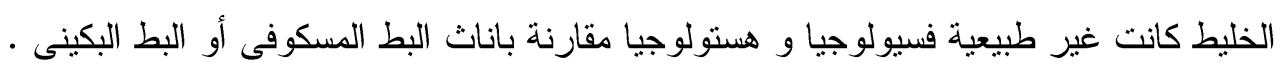

